Research Article

\title{
Brilliant Green Dye Biosorption Using Activated Carbon Derived from Guava Tree Wood
}

\author{
R. A. Mansour, ${ }^{1}$ Abeer El Shahawy $\mathbb{D}^{2},{ }^{2}$ A. Attia, ${ }^{3,4}$ and Mokhtar S. Beheary ${ }^{5}$ \\ ${ }^{1}$ Chemical Engineering Department, Higher Institute of Engineering and Technology, New Damietta, Egypt \\ ${ }^{2}$ Department of Civil Engineering, Faculty of Engineering, Suez Canal University, P O. Box 41522, Ismailia, Egypt \\ ${ }^{3}$ Department of Chemistry, Faculty of Science, Mansoura University, Mansoura, Egypt \\ ${ }^{4}$ Faculty of Science and Arts, Chemistry Department, Najran University, Najran, Saudi Arabia \\ ${ }^{5}$ Department of Environmental Science, Faculty of Science, Port Said University, Port Fuad, Egypt \\ Correspondence should be addressed to Abeer El Shahawy; ahmedabeer12000@yahoo.com
}

Received 21 September 2019; Revised 1 February 2020; Accepted 14 February 2020; Published 20 July 2020

Academic Editor: Doraiswami Ramkrishna

Copyright (C) 2020 R. A. Mansour et al. This is an open access article distributed under the Creative Commons Attribution License, which permits unrestricted use, distribution, and reproduction in any medium, provided the original work is properly cited.

\begin{abstract}
The removal of brilliant green (BG) dye from an aqueous solution using activated carbon (AC) derived from guava tree wood is conducted in batch conditions. The influence of different factors such as contact time, $\mathrm{pH}$, adsorbent dosage, initial dye concentration, and temperature on the adsorption of BG onto AC was investigated. FTIR, BET, and SEM analyses were performed to determine the characteristics of the material. The isotherm results were analyzed using the Langmuir, Freundlich, Temkin, and Dubinin-Radushkevich isotherms. Linear regression was used to fit the experimental data. It was found that the equilibrium data are best represented by the Freundlich isotherm, and the adsorption capacity $\left(q_{e}\right)$ was $90 \mathrm{mg}$ dye/g AC. The values of the free energy $(\Delta G)$, enthalpy $(\Delta H)$, and entropy $(\Delta S)$ were $-86.188 \mathrm{~kJ} / \mathrm{mol}, 43.025 \mathrm{~kJ} / \mathrm{mol}$, and $128 \mathrm{~J} / \mathrm{mol} . \mathrm{K}$, respectively, at $\mathrm{pH} 7 \mathrm{for}$ the BG dye. The kinetics of BG dye adsorption were analyzed using pseudo-first-order and pseudo-second-order models, and it was found that the pseudo-second-order model was suitable for the behavior of the BG dye at $R^{2}=0.999$.
\end{abstract}

\section{Introduction}

Dyes are widely used in several industrial applications such as in textiles, plastics, printing, rubber, cosmetics, paper and pulp, leather, and pharmaceutical [1-3]. The effluents of these industries are usually discharged into the water stream body which may cause harmful effects to the human and aquatic life beings due to their carcinogenic, toxic, and mutagenic effects [1].

Brilliant green is a basic dye in various industrial and medical applications, e.g., biological stain, dermatological agent, veterinary medicine, an additive to poultry feed to prevent the spread of mold, intestinal parasites, and fungus [2], and also used in paper printing and textile dying. BG dye is dangerous in case of skin contact, eye contact, and swallowing. It is toxic to the lungs, through inhalation. During its degradation, it may form carbon dioxide, nitrogen oxide, and sulfur oxides. Therefore, there is an urgent need to separate this dye from the wastewater [3-8].
Different treatment techniques (physical, chemical, and biological) have been used to separate colored compounds from wastewater. Biological degradation, photochemical degradation, flocculation, coagulation, reverse osmosis, chemical oxidation, floatation, and adsorption are widely used [9-11]. Adsorption on activated carbon (AC) is commonly used owing to its high efficiency and ability to remove many chemical compounds [12], simplicity of design [13], and economic feasibility. Nevertheless, the large-scale usage of $\mathrm{AC}$ is restrained when it is produced from expensive and nonrenewable precursors [14].

Although activated carbon as an adsorbent for dye removal is commercially available, it is not cost effective and has some environmental concerns. It is commonly produced from very expensive materials such as lingocellulosic materials and coal, which are not renewable. This increases the preparation cost considerably. This has motivated researchers to find and test alternative sources with feasible 
methods for the preparation of AC compared to the currently available techniques. One of the viable and promising methods of producing AC is ant wastes or agricultural byproducts such as saw dust, wood, banana pith, fruit stones, and coconut husks. Because of their merits of low cost, availability, and ecofriendliness [15], anion-exchange resins such as IRA 402 and IRA-400 have been applied in the aqueous medium for both batch and column adsorption processes. Sinha et al. [16] have examined the sorption of the Congo Red (CR) azo dye from aqueous solutions using the Amberlite IRA-400 resin in batch and fixed bed reactors.

As mentioned above, it is economical to prepare highquality AC from abundant, cheap, renewable, and sustainable precursors such as biomass-based agroindustrial byproducts $[17,18]$. Guava tree wood is an important source of activated carbon and is widely used in turnery and carpentry. In addition, this wood is excellent as a fuel and a valuable resource for charcoal.

In this study, AC prepared from guava tree wood is used for the adsorption of the BG dye from an aqueous solution. The adsorption efficiency of $\mathrm{AC}$ can be identified by different factors such as $\mathrm{pH}, \mathrm{AC}$ dose, contact time, temperature, and initial dye concentration. Textural characterization of the prepared AC was carried out by BET, FTIR, and SEM. Additionally, the kinetic, thermodynamic, and isotherm studies were carried out.

\section{Experimental Work}

2.1. Brilliant Green Dye and Solutions. BG was purchased from Merck Company (Germany) and was used without any further purification. It is an organic compound that is classified as a basic cationic dye. It has a molecular formula as $\mathrm{C}_{27} \mathrm{H}_{33} \mathrm{~N}_{2} \mathrm{O}_{4} \mathrm{~S}$, and its molecular weight is $482.64 \mathrm{~g} / \mathrm{g} \cdot \mathrm{mol}$. One gram of the BG dye was dissolved in a liter of distilled water to get a dye concentration of $1000 \mathrm{mg} / \mathrm{l}$. The concentration of the other solutions tested in the current study can be changed by the diluting method. The $\mathrm{pH}$ value was adjusted with sodium hydroxide or hydrochloric acid solutions $(0.1 \mathrm{M})$.

2.2. Preparation of Adsorbent. AC was prepared from the guava tree wood, which was collected from Damietta city, Egypt. A given amount of crushed guava wood was heated at $700-900^{\circ} \mathrm{C}$ for one hour. After that, it was allowed for cooling to room temperature $\left(25 \pm 4^{\circ} \mathrm{C}\right)$. The powder was treated with $1 \mathrm{M} \mathrm{HCl}$ solution to eliminate the ash content and then washed with distilled deionized water. Further, the treated powder was dried at $105^{\circ} \mathrm{C}$ for $24 \mathrm{~h}$. The final product was stored in closed glass containers. The prepared AC was screened by a 40 mesh sieve and was used as an adsorbent [19].

2.3. Batch Adsorption Studies. Batch technique was used in this study. A polluted water sample $(50 \mathrm{ml})$ containing a known concentration of the BG dye (varied from 5 to $100 \mathrm{ppm}$ ) was transferred to a glass stoppered bottle $(250 \mathrm{ml})$. The flasks were kept in a thermostatic water bath shaker at a constant speed of $240 \mathrm{rpm}$ for $20 \mathrm{~min}$. The batch experiments were carried out at $293 \mathrm{~K}$ to determine the retention kinetic of $\mathrm{BG}$ on activated carbon. $0.8 \mathrm{~g}$ of activated carbon dissolved in $50 \mathrm{ml}$ dye solution ( $\mathrm{pH} 7$ ) was shaken for different times to attain equilibrium distribution, and the batch experiment was repeated twice, and the data were averaged for the dye. The retention capacity of the BG dye adsorbed by AC was determined from the difference between the initial and final dye concentration in the aqueous solution before and after retention. The concentration of the BG dye was analyzed using a spectrophotometer (UV/Vis spectrophotometer) at $\lambda_{\max }(625 \mathrm{~nm})$. The amount of dye retained per unit mass of the adsorbent and the percent removal $(\% R)$ of the dye were calculated by

$$
\begin{gathered}
\% R=\frac{C_{i}-C_{f}}{C_{i}} * 100, \\
q_{e}=\left(C_{i}-C_{e}\right) * \frac{v}{m},
\end{gathered}
$$

where $q_{e}$ is the adsorption capacity $(\mathrm{mg} / \mathrm{g}), C_{i}$ is the initial concentration of the dye in $(\mathrm{mg} / \mathrm{l}), C_{e}$ is the concentration of the BG dye ( $\mathrm{mg} / \mathrm{l})$ at equilibrium, $C_{i}$ and $C_{f}$ are the initial and final concentrations of the $\mathrm{BG}$ dye $(\mathrm{mg} / \mathrm{l})$ respectively, $v$ is the volume of the solution (l), and $m$ is the amount of the adsorbent (g).

2.4. Equilibrium Studies and Adsorption Isotherm. The most commonly used representation of the adsorbate concentration and quantity of the pollutant adsorbed is the adsorption isotherm. The equilibrium adsorption isotherm is fundamental in describing the interactive behavior between the solute and the adsorbent and is important for the design of an adsorption system equilibrium of BG dye adsorption. It was modeled by the following important isotherms.

2.4.1. Langmuir Isotherm. The Langmuir adsorption model describes monolayer adsorption of the adsorbate onto a homogeneous adsorbent surface [20]. This model also determines the maximum capacity of the adsorbent [21]:

$$
\frac{C_{e}}{q_{e}}=\frac{1}{q_{m}} C_{e}+\frac{1}{q_{m} k_{L}},
$$

where $q_{\mathrm{e}}$ is the amount of the dye at equilibrium $(\mathrm{mg} / \mathrm{g}), q_{\mathrm{m}}$ is the maximum adsorption capacity $(\mathrm{mg} / \mathrm{g})$, and $k_{L}$ is the Langmuir constant (L/mg).

2.4.2. Freundlich Isotherm. The Freundlich isotherm model is often used for heterogeneous surface energy systems and is represented by the following equation:

$$
\ln q_{e}=\frac{1}{n} \ln C_{e}+\ln k_{f},
$$

where $C_{e}$ is the equilibrium concentration in the liquid phase $(\mathrm{mg} / \mathrm{l}), q_{e}$ is the adsorption capacity $(\mathrm{mg} / \mathrm{g}), k_{f}$ is the Freundlich constant representing adsorption capacity, and 
" $n$ " is the empirical parameter representing the energetic heterogeneity of the adsorption sites.

2.4.3. Temkin Isotherm. The nonlinear form of the Temkin equation is given by

$$
q_{e}=q_{m} \ln \left(K_{t} C_{e}\right)
$$

This equation can be linearized as given by

$$
q_{e}=q_{m} \ln K_{t}+q_{m} \ln C_{e},
$$

where $q_{m}$ is a constant related to the heat of adsorption ( $\mathrm{J} /$ mole) and $k_{t}$ is the equilibrium binding constant $(1 / \mathrm{g})$ corresponding to the maximum binding energy. The isotherm constants $k_{t}$ and $q_{m}$ are determined by the slope and intercept from a plot of $q_{e}$ versus $\ln \left(C_{e}\right)$.

2.4.4. Dubinin-Radushkevich Isotherm. Dubinin isotherm can be expressed in the linear form as follows:

$$
\begin{aligned}
\ln q_{e} & =\ln q_{m}-D \varepsilon^{2}, \\
\varepsilon & =R T \ln \left(1+\frac{1}{C_{e}}\right),
\end{aligned}
$$

where $D$ is a constant related to the transfer energy, $R$ is the gas constant $\left(\mathrm{kJmol}^{-1} \mathrm{~K}^{-1}\right), q_{\mathrm{m}}$ is the Dubinin constant $\left(\mathrm{mgg}^{-1}\right)$, and $T$ is the absolute temperature in $(\mathrm{K})[22,23]$.

2.5. Kinetic Studies. The adsorption of the BG dye was characterized by two kinetic models as follows:

2.5.1. Pesudo-First Order. The pseudo-first-order kinetic model can be written as follows:

$$
\log \left(q_{e}-q_{t}\right)=\log q_{e}-\frac{K_{1} t}{2.303}
$$

where $q_{e}$ and $q_{t}$ are the amount of dye sorbed per mass of the sorbent at equilibrium $\left(\mathrm{mg} \mathrm{g}^{-1}\right)$ and at any time $(\mathrm{t})$, respectively, and $k_{1}$ is the rate constant $\left(\mathrm{min}^{-1}\right)$.

\subsubsection{Pseudo-Second Order. This model is represented by}

$$
\frac{t}{q_{t}}=\frac{1}{k 2 q_{e}^{2}}+\frac{1}{q_{e}} t,
$$

where $k_{2}$ is the rate constant and $q_{t}$ is the dye uptake capacity at any time $t$.

2.6. Thermodynamic Study. Thermodynamic parameters for the adsorption of BG on the adsorbent are evaluated by the equilibrium experimental data observed at different temperatures from 298.15 to $358.18 \mathrm{~K}$. There is a set of thermodynamic parameters that can be used to describe the adsorption process which are the change of enthalpy $(\Delta H$, $\left.\mathrm{kJ} \mathrm{mol}^{-1}\right)$, Gibbs energy $\left(\Delta G, \mathrm{~kJ} \mathrm{~mol}^{-1}\right)$, and entropy $(\Delta S$, $\mathrm{kJ} \mathrm{mol}^{-1} \mathrm{~K}^{-1}$ ) [24]. These parameters were calculated using the Van't Hoff equations $[25,26]$. This is given as follows:

$$
\begin{aligned}
\Delta G & =-R T \ln K, \\
K & =\frac{q_{e}}{c_{e}}, \\
\Delta G & =\Delta H-T \Delta S,
\end{aligned}
$$

where $K$ is the equilibrium constant $\left(\mathrm{g}^{-1}\right), T$ is the temperature (K), $R$ is the universal gas constant $(8.314 \mathrm{~J} / \mathrm{mol} . \mathrm{K})$, and $q_{e}$ is the adsorption capacity $\left(\mathrm{mg} \mathrm{g}^{-1}\right)$. By plotting the graph between $1 /$ $T$ and $\ln (k)$, the values of $\Delta H$ and $\Delta S$ of the adsorption process were estimated from the slope and the intercept.

\section{Results and Discussion}

3.1. Characterization of $A C$. In order to obtain information about the mode of interaction of the brilliant green dye with activated carbon, different physicochemical measurements were done, which are presented below.

3.1.1. Scanning Electron Microscopy (SEM). Figures 1(a) and 1(b) show the SEM image of AC and adsorbed BG onto AC, respectively. The SEM image of the AC sample before dye adsorption (Figure 1(a)) obviously shows the surface morphology with an irregular texture and high surface roughness and different levels of porosity in AC, which provides possible sites for adsorption of the dye. The surface roughness and the macropores which are important factors for the dye adsorption were responsible for the high surface area, making AC a good adsorbent. After adsorption with the dye, a large area of AC was covered with dye molecules in the form of flakes, and thus the SEM image of AC after adsorption showed a smooth surface because the BG molecules were trapped and sorbed on the surface of AC.

3.1.2. Fourier-Transform Infrared (FTIR) Spectra. A substantial part of the knowledge concerning the mode of the bonding in the dye compound can be gained by applying infrared spectra. In such a case, the spectrum of AC is usually compared with that of the AC-dye species to get an idea about the function groups which react with the dye. The IR spectra of the sorbed species and AC are depicted in Figure 2.

Figure 2 represents the FTIR spectrum of the adsorbent (AC) before and after adsorption. The FTIR spectrum of AC showed different bands at 3440, 2918, 1598, 1452, and 782 $\mathrm{cm}^{-1}$ assigned to $\mathrm{O}-\mathrm{H},-\mathrm{CH}$ aliphatic, $-\mathrm{C}=\mathrm{C},-\mathrm{CH}_{2}$ bending, and $-\mathrm{C}=\mathrm{S}$. The FTIR spectrum of AC-BG compared with that of AC showed that there are bands at 3442, 2920, 1583, 1440, and $811 \mathrm{~cm}^{-1}$ assigned to $\mathrm{O}-\mathrm{H},-\mathrm{CH}$ aliphatic, $-\mathrm{C}=\mathrm{C},-\mathrm{CH}_{2}$ bending, and $-\mathrm{C}=\mathrm{S}$. The FTIR spectrum of the $\mathrm{AC}-\mathrm{BG}$ showed shifts in bands to higher and/or to lower with appearance or disappearance of other bands, which indicate the complete adsorption of the BG dye.

3.1.3. BET. The specific surface area of the prepared AC was obtained by the nitrogen adsorption/desorption isotherm at $77 \mathrm{~K}$ using the high-speed gas sorption analyzer (NOVA 1000, 

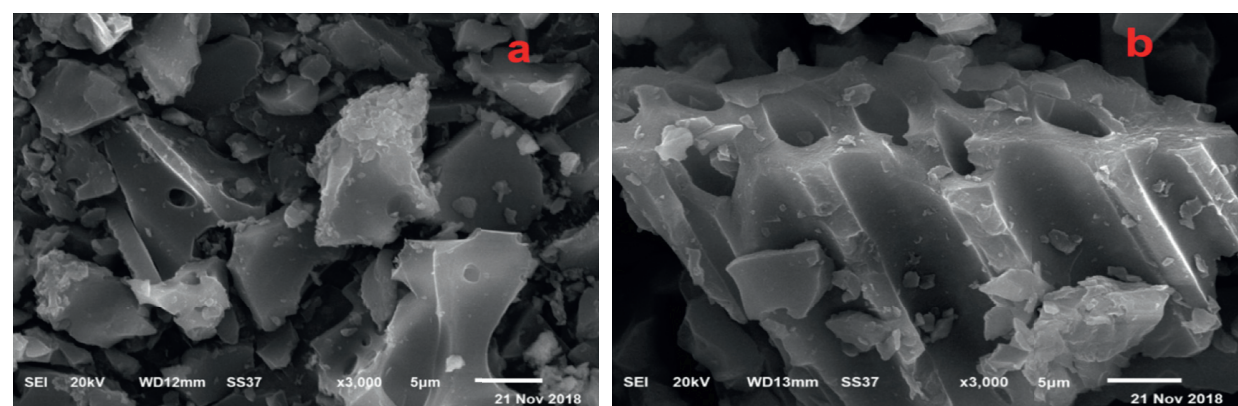

Figure 1: SEM images of the AC adsorbent. (a) AC only and (b) AC+BG dye.

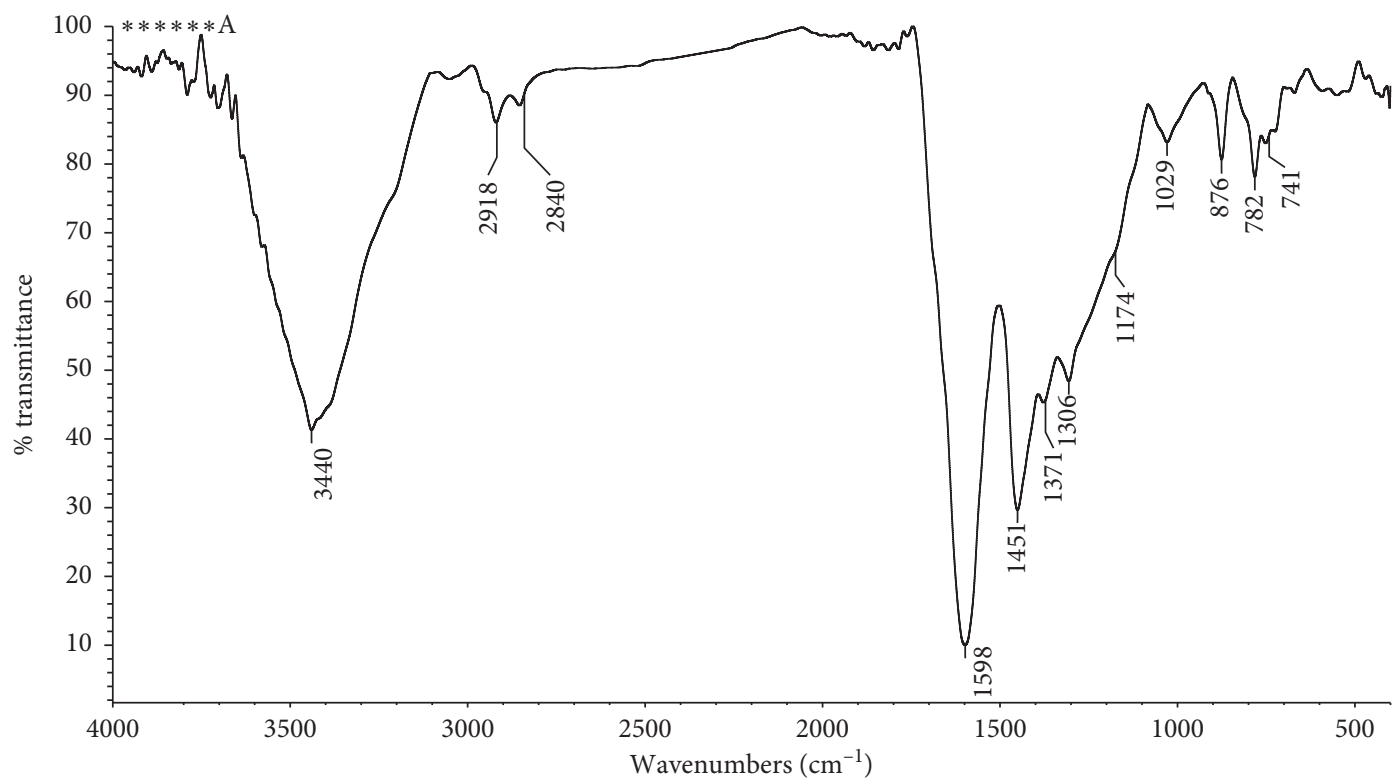

(a)

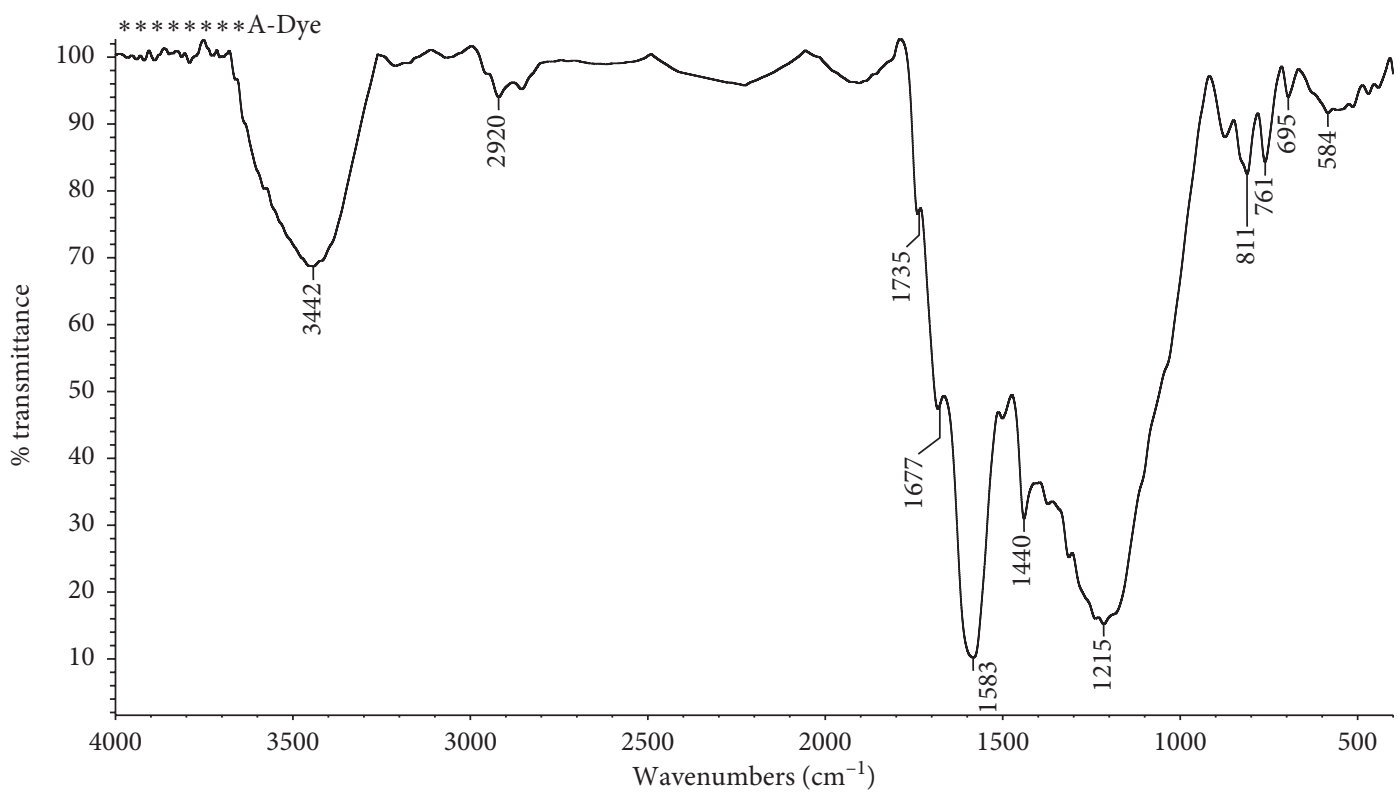

(b)

FIGURE 2: FTIR for (a) activated carbon and (b) activated carbon with brilliant green dye. 
Version 6.11, Quanta Chrome Corporation) employing the Brunauer-Emmett-Teller (BET) method (activation temperature of $900^{\circ} \mathrm{C}$ and activation time $0.5 \mathrm{hr}$.). The specific surface area was found to be equal to $310 \mathrm{~m}^{2} / \mathrm{g}$. This area can provide many active sites that increase the chances of adsorption.

\subsection{Affecting Parameters on Adsorption}

3.2.1. Effect of $p H$. The $\mathrm{pH}$ value is an important parameter in controlling the adsorption process due to the ionization of surface functional groups in the solution [27]. To study the influence of $\mathrm{pH}$ on the adsorption of the $\mathrm{BG}$ dye onto $\mathrm{AC}$, experiments were performed using various initial $\mathrm{pH}$ values varying from 2 to 12 . The results indicate that the percentage removal of the $\mathrm{BG}$ dye increases with the increase in $\mathrm{pH}$ up to a $\mathrm{pH}$ value of 7 (Figure 3), after which the removal of $\mathrm{BG}$ dye decreases with the increase in $\mathrm{pH}$. At lower $\mathrm{pH}$ values, the $B G$ removal was reduced, probably as a result of the competition between hydrogen ions and the dye cations for the sorption sites of AC [28]. The surface of the AC may get negatively charged at higher $\mathrm{pH}$, which increases the chances of attraction force with the cationic dye through electrostatic force of attraction [29]. Generally, the net positive charge decreases with increasing $\mathrm{pH}$ value leading to the decrease in the repulsion force between the adsorbent surface and the dye, thus improving the adsorption capacity.

3.2.2. Effect of Adsorbent Dose. Figure 4 shows the influence of AC mass on the removal of BG dye from aqueous solutions. With an increase in the amount of the adsorbent material, the uptake of the dye increases. The adsorption of the BG dye increases significantly (from $83 \%$ to $99 \%$ ) when the adsorbent dose increases from $0.1 \mathrm{~g}$ to $0.8 \mathrm{~g}$, but the removal efficiency of the dye does not change significantly when the adsorbent dose is increased above $0.8 \mathrm{~g}$. So, $0.8 \mathrm{~g}$ of the adsorbent (AC) can be considered the optimal dose for the adsorption of the BG dye. For the brilliant green dye, it is clear that the percentage removal increased gradually as the adsorbent mass increased. This effect can be attributed to the increase in the surface area and the active sites of the adsorbent [30].

3.2.3. Effect of Initial Dye Concentration. The influence of initial dye concentration $\left(C_{i}\right)$ was studied in the range $(5-100 \mathrm{mg} / \mathrm{l})$ at temperature $25^{\circ} \mathrm{C}, 240 \mathrm{rpm}$, and $20 \mathrm{~min}$ contact time, and the results are shown in Figure 5. From Figure 5, the removal efficiency of the activated carbon decreased with increasing initial dye concentration. There will be unoccupied active sites on the AC surface at low dye concentration, and the active sites required for adsorption of the BG molecules will be lacking when the initial dye concentration increases [31].

3.3. Adsorption Isotherm. The adsorption isotherms were determined by shaking $0.8 \mathrm{~g}$ of the AC with $50 \mathrm{ml}$ of 5 to $100 \mathrm{mg} / \mathrm{l}$ of BG solutions for $20 \mathrm{~min}$. The adsorption isotherms are used to relate the adsorbed amount at the interface and the adsorbent concentration in the bulk solution [32] and is important for the design of an adsorption system.

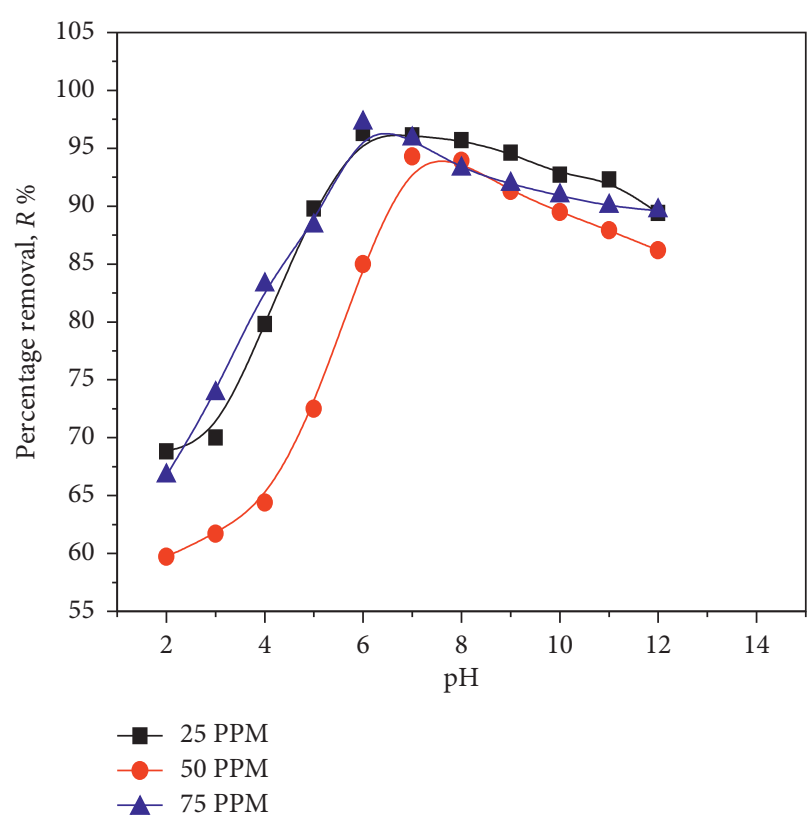

Figure 3: Effect of $\mathrm{pH}$ on the adsorption of the BG dye using AC.

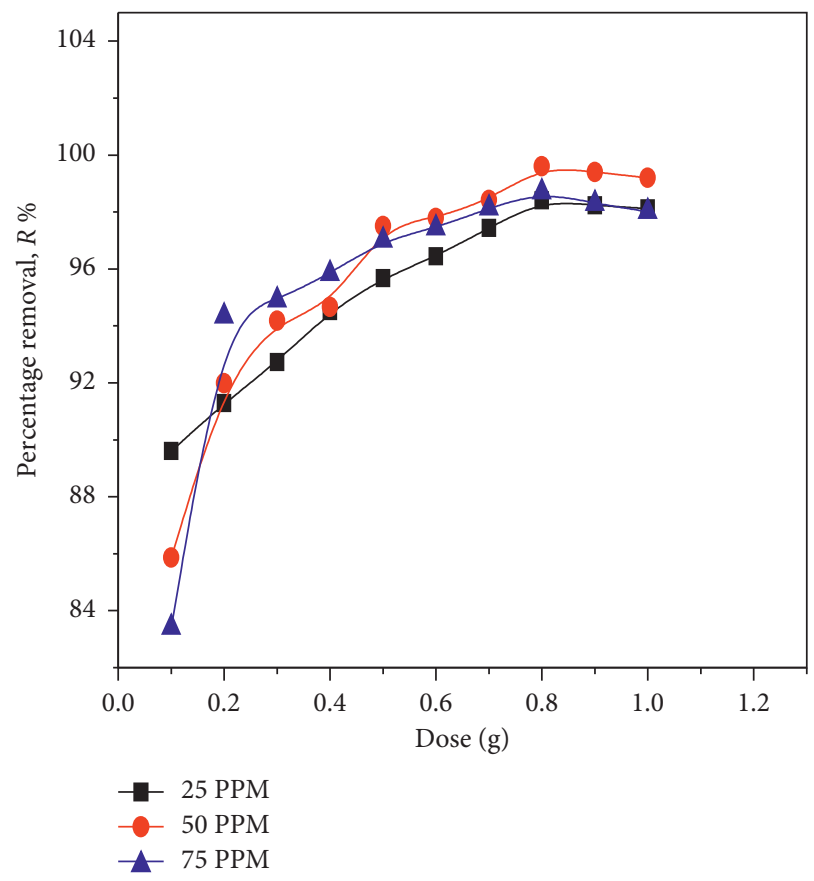

FIGURE 4: Effect of adsorbent dosage on the adsorption of the BG dye using AC.

The correlation coefficient values $\left(R^{2}\right)$ were used as a criterion to infer the most appropriate isotherm equation that can be selected to describe the adsorption process.

3.3.1. Langmuir Isotherm. The linear form can be used for the linearization of experimental data by plotting $C_{e} / q_{e}$ against $C_{\mathrm{e}}$ (Figure 6). The Langmuir constant $q_{m}(\mathrm{mg} / \mathrm{g})$ which is a measure of the maximum adsorption capacity of AC is obtained as $90 \mathrm{mg} / \mathrm{g}$. $K_{m}$ is the Langmuir constant 


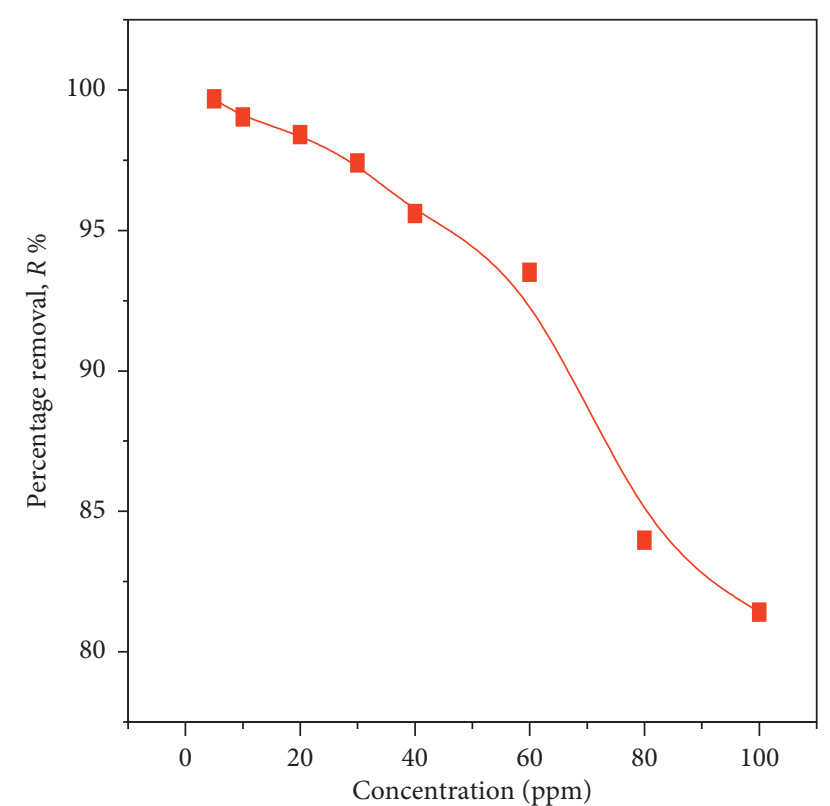

FIGURE 5: Effect of initial dye concentration on the adsorption onto AC.

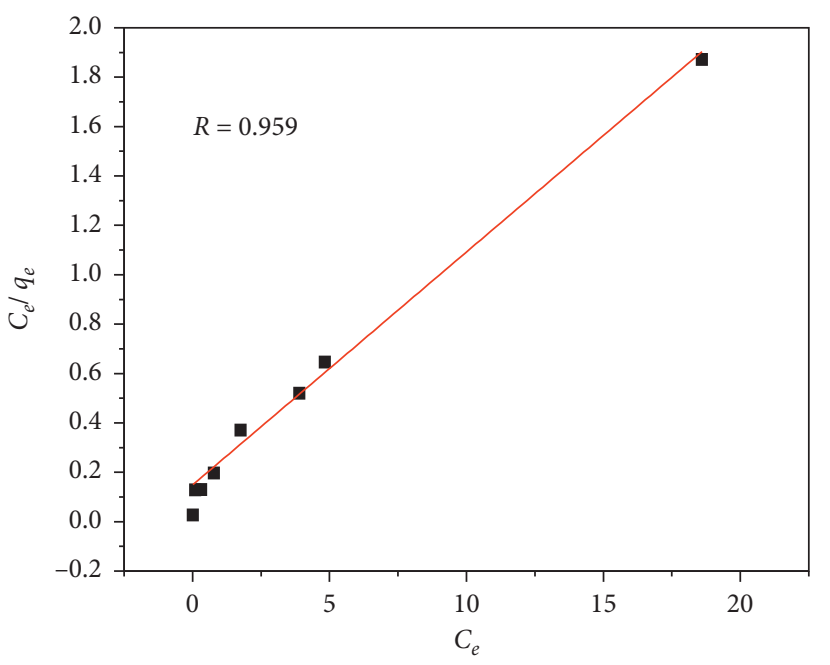

FIgURE 6: Langmuir model for brilliant green dye onto AC.

which relating to adsorption energy is found to be $0.14 \mathrm{mg}^{-1}$ for the brilliant green dye. The feasibility of the process can be evaluated by a separation factor (dimensionless constant) " $\mathrm{R}_{\mathrm{L}}$ " which is given in the following equation:

$$
R_{L}=\left(\frac{1}{1}+K_{L} C_{i}\right)
$$

where " $C_{i}$ " is the initial dye concentration $(\mathrm{mg} / \mathrm{L})$ and the " $R_{L}$ " value is between zero and one for favorable adsorption, whereas $\left(R_{L}>1\right),\left(R_{L}=1\right)$, and $\left(R_{L}=\right.$ zero $)$ for unfavorable, linear, and irreversible adsorption, respectively [7].

3.3.2. Freundlich Isotherm. By plotting the graph between $\ln \left(q_{e}\right)$ and $\ln \left(c_{e}\right)$ (Figure 7$)$, the Freundlich constants $\left(K_{F}\right.$ and $\left.n\right)$

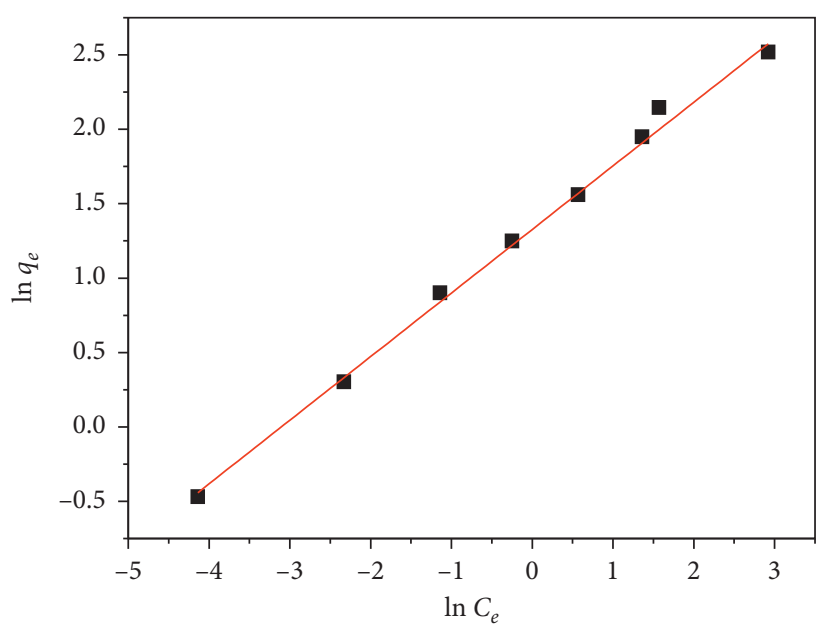

FIgURE 7: Freundlich model for brilliant green dye onto AC.

can be obtained from the slope and the intercept of the linear plot of the experimental data. The values of $K_{f}$ and $n$ are 0.427 and 1.326, respectively. The value of $n$ indicates the degree of nonlinearity between solution concentration and adsorption; if $n=1$, then adsorption is linear; if $n<1$, then adsorption is a chemical process; if $n>1$, then adsorption is a physical process [33]. The $n$ value was found to be 1.326 for AC. Since $n>1$, the adsorption of the BG dye onto AC is a physical process. It is found that the correlation coefficient value $\left(R^{2}\right)$ obtained from the Freundlich isotherm model for $\mathrm{AC}$ is 0.975 for the dye.

3.3.3. Temkin Isotherm. The Temkin model suggested that the heat of adsorption of all the molecules in the layer would decrease linearly with coverage, and the distribution of binding energy is uniform during the adsorption process [34].

A plot of $\ln \left(C_{e}\right)$ versus $q_{\mathrm{e}}$ (Figure 8 ) at $25^{\circ} \mathrm{C}$ is used to calculate the Temkin isotherm constants $\left(q_{m}\right.$ and $\left.K_{t}\right)$. The constants $q_{m}$ and $K_{t}$ are 5.18 and 1.48, respectively. The obtained $R^{2}$ for the Temkin isotherm model is 0.863 for the dye.

3.3.4. Dubinin-Radushkevich Isotherm. The plot between $\ln \left(q_{e}\right)$ and $\varepsilon^{2}$ (Figure 9) at $25^{\circ} \mathrm{C}$ is used to calculate the constants $q_{m}$ and $D$ whose values are 2.31 and 0.53 , respectively. The value of $R^{2}$ is 0.732 .

The isotherm constants and $R^{2}$ which were computed from the above four isotherms are tabulated in Table 1. From the values of $R^{2}$, it is strongly suggested that the adsorption of BG onto AC data fits well with the Freundlich isotherm. Finally, the adsorption is a multilayer adsorption and takes place on heterogeneous surfaces.

3.4. Adsorption Kinetics. The influence of contact time on the adsorption of $\mathrm{BG}$ onto $\mathrm{AC}$ was studied to detect the equilibrium time and to investigate the adsorption process. Plots of the change in contact time (5-60 min) versus dye removal percent are presented in Figure 10. The removal of 


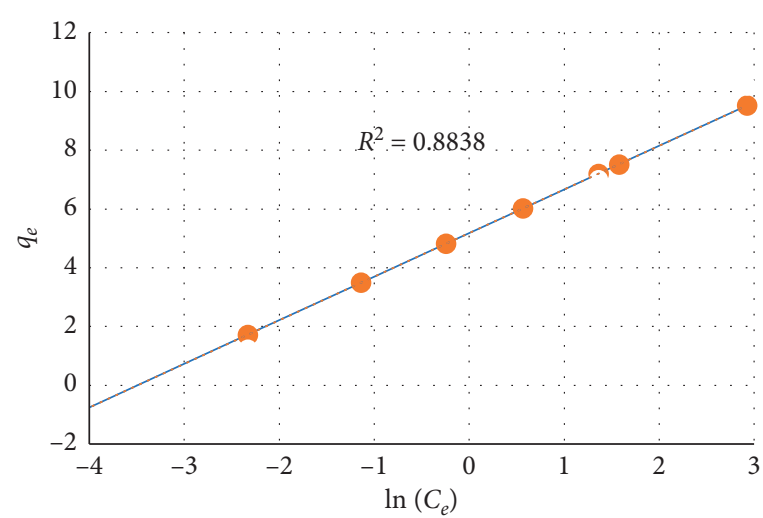

Figure 8: Temkin model for brilliant green dye onto AC.

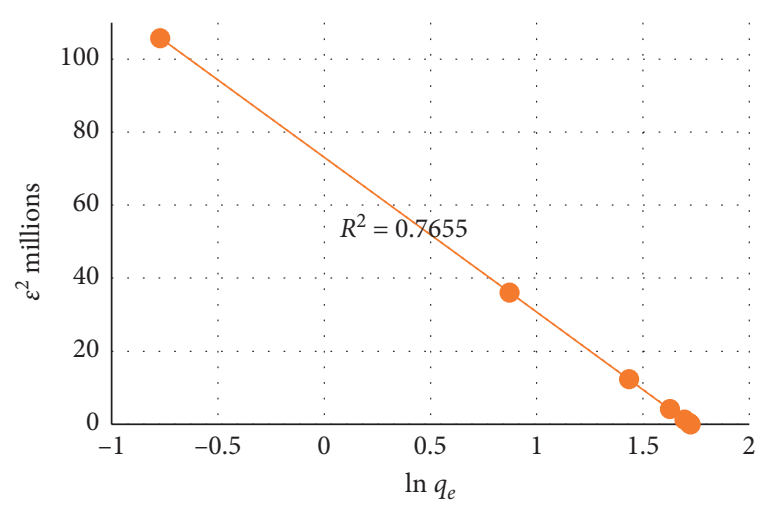

Figure 9: Dubinin model for brilliant green dye onto AC.

TABLE 1: Isotherm models and their linearized expression with their parameters for adsorption of the BG dye on AC.

\begin{tabular}{lccc}
\hline & Adsorption isotherm & Parameters & $R^{2}$ \\
\hline 1 & Langmuir & $\begin{array}{c}q_{m}=90 \\
K_{m}=0.14\end{array}$ & 0.959 \\
\hline 2 & Freundlich & $\begin{array}{c}K_{f}=0.427 \\
n=1.326\end{array}$ & 0.975 \\
\hline 3 & Temkin & $\begin{array}{c}q_{m}=5.18 \\
K_{t}=1.48\end{array}$ & 0.863 \\
\hline 4 & Dubinin-Radushkevich & $\begin{array}{c}q_{m}=2.31 \\
D=0.53\end{array}$ & 0.732 \\
\hline
\end{tabular}

BG by sorption onto $\mathrm{AC}$ was found to be rapid at the initial period of contact time and then to become slow with the increase in contact time. This is probably due to the larger surface area being available at the beginning for the adsorption of BG dye onto AC. The adsorption of the dye on the $\mathrm{AC}$ reaches equilibrium after $20 \mathrm{~min}$. Therefore, a contact time of $20 \mathrm{~min}$ for the dye was applied for the further studies as the adsorption equilibrium time. At any time $t$, the amount of dye taken $\left(q_{t}, \mathrm{mg} / \mathrm{g}\right)$ on the adsorbent was computed by the following model [35]:

$$
q_{t}=\left(C_{0}-C_{t}\right) \frac{v}{m} \text {. }
$$

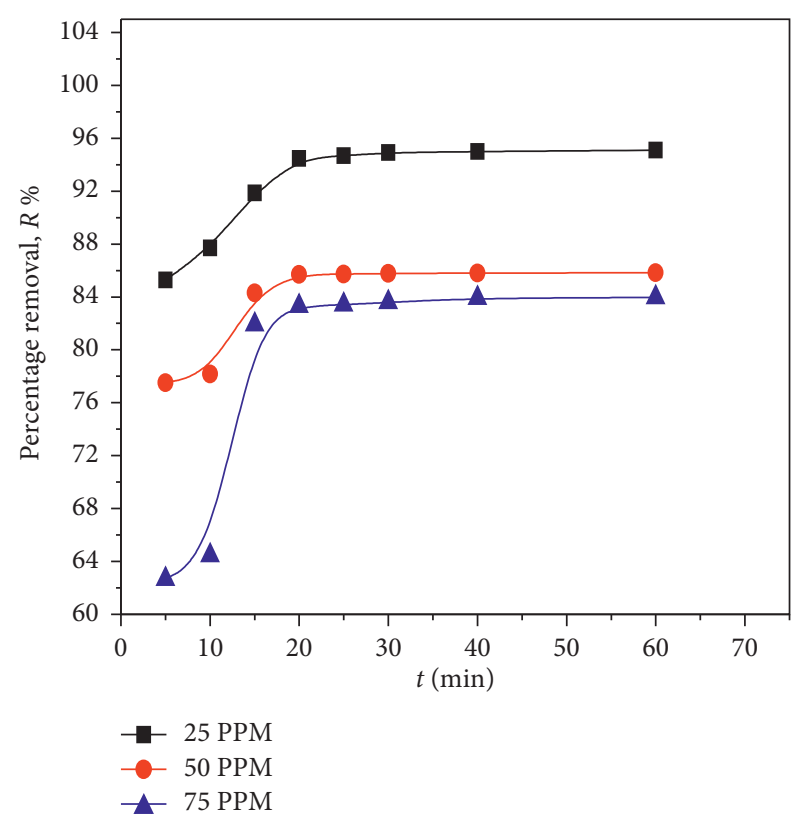

FIGURE 10: Effect of contact time on the adsorption of BG dye onto AC.

In order to investigate the mechanism of the adsorption and potential rate-controlling steps such as mass transfer and chemical reaction, the kinetics of BG sorption onto AC were investigated by using two different models: the pseudofirst-order and pseudo-second-order kinetic models [36].

3.4.1. Pseudo-First-Order Kinetics. The slope and intercept of the plot $\log \left(q_{e}-q_{t}\right)$ versus $t$ (Figure 11) give a straight line which represents the pseudo-first-order rate constants $\left(k_{1}\right.$ and $q_{e}$ ). The values of $k_{1}$ and $q_{e}$ for the initial dye concentration are listed in Table 2 . The value of $R^{2}$ is found to be 0.932 for the dye.

3.4.2. Pseudo-Second-Order Kinetics. The slope of the straight line and intercept resulted by plotting $t / q_{\mathrm{t}}$ against $t$ is shown in Figure 12 and presented in Table 2. The value of $R^{2}$ is found to be 0.999 for the dye. The BG adsorption on AC is well convenient with pseudo-second-order kinetics $\left(R^{2}=0.999\right)$. Thus, the pseudo-second-order kinetic expression can be used to predict successfully the amount of BG dye adsorbed at equilibrium using the kinetic experimental data.

3.5. Thermodynamic Studies. The influence of temperature on the adsorption of $\mathrm{BG}$ onto $\mathrm{AC}$ was investigated in the temperature range of $25-95^{\circ} \mathrm{C}$ (Figure 13). The uptakes of $\mathrm{BG}$ dye by $\mathrm{AC}$ increase on increasing the temperature, confirming the endothermic nature of the retention step.

To understand more the effect of temperature on the adsorption process, the thermodynamic parameters, including the change in enthalpy $\left(\Delta H, \mathrm{KJ} \mathrm{mol}^{-1}\right)$, Gibbs free energy $\left(\Delta G, \mathrm{KJ} \mathrm{mol}^{-1}\right)$, and entropy $\left(\Delta S, \mathrm{~J} \mathrm{~mol}^{-1} \mathrm{~K}^{-1}\right)$, were determined. The inherent energy, structural changes, 


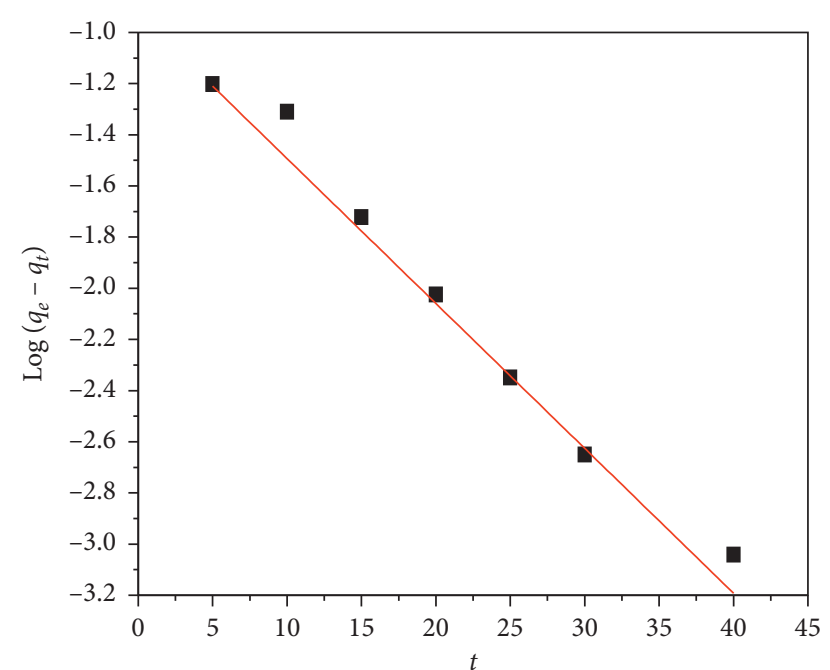

FIGURe 11: Pseudo-first order for adsorption of brilliant green dye onto AC.

TABLE 2: Kinetic parameters for the adsorption of BG onto AC.

\begin{tabular}{lccc}
\hline No. & \multicolumn{2}{c}{ Parameters } & $R^{2}$ \\
\hline 1 & Pseudo-first order & $k_{1} \times 103=-0.05 q_{e}=-0.92$ & 0.932 \\
2 & Pseudo-second order & $k_{2} \times 103=1.65 q_{e}=1.11$ & 0.999 \\
\hline
\end{tabular}

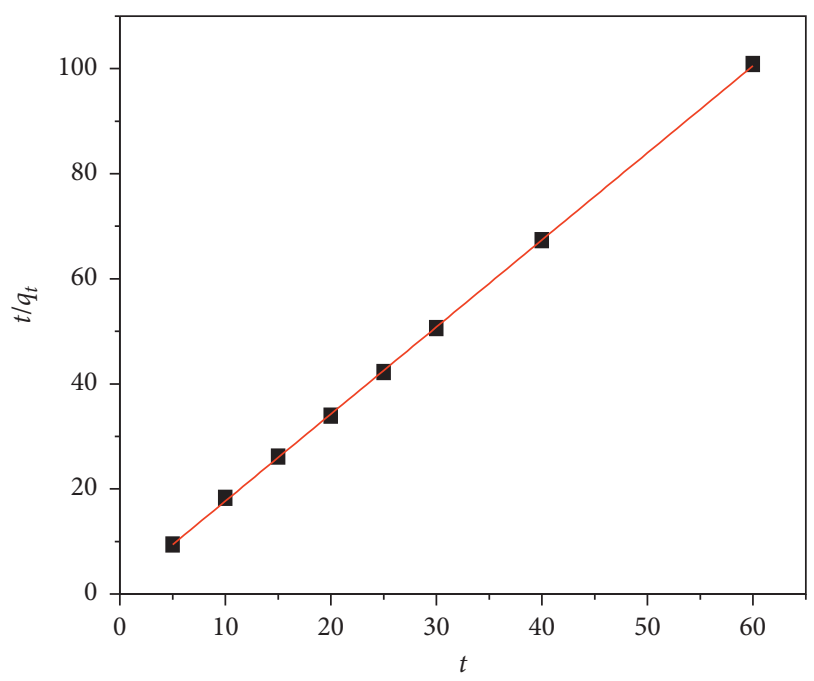

Figure 12: Pseudo-second order for adsorption of brilliant green dye onto AC.

orientation, and feasibility of the adsorption reaction are associated with these parameters [37].

The thermodynamic parameters $\Delta H, \Delta S$, and $\Delta G$ of the dye sorption from the aqueous solution onto the $\mathrm{AC}$ were calculated employing equations (9)-(11). The plot of $q_{e} / C_{e}$ versus $1 / T$ was linear over the temperature range of $298.15-368.15 \mathrm{~K}$. The values of $\Delta H, \Delta S$, and $\Delta G$ computed from the slope and the intercept (Figure 14) and (Table 3) were found equal to $43.025 \mathrm{~kJ} / \mathrm{mol},-128 \mathrm{~J} / \mathrm{mol} . \mathrm{K}$, and $86.188 \mathrm{~kJ} / \mathrm{mol}$, respectively. The value of $\Delta H$ confirms the endothermic nature of the brilliant green dye. This

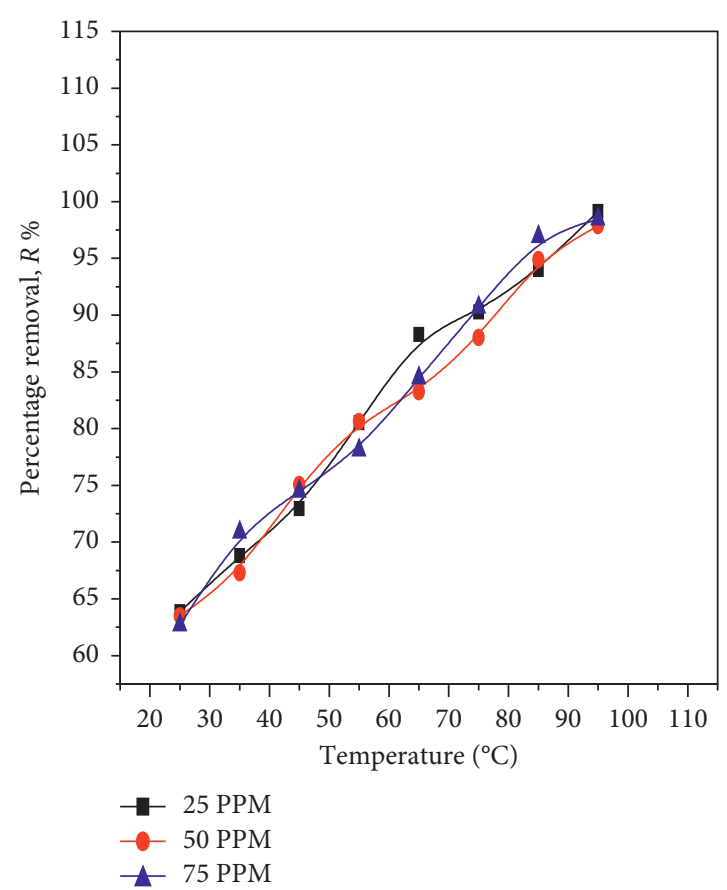

FIgURE 13: Effect of temperature on the adsorption of dye onto AC.

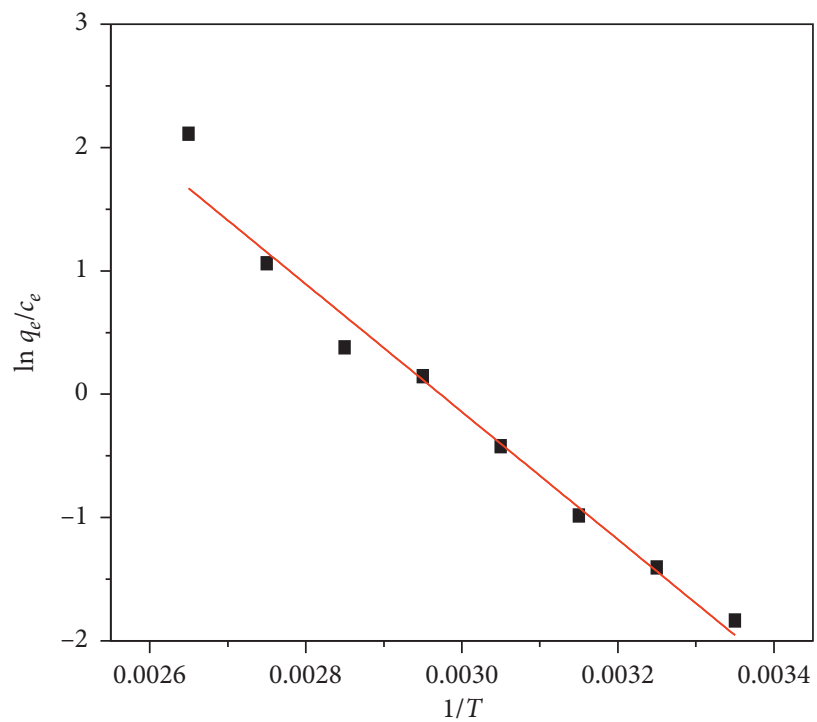

FIgURE 14: Thermodynamic parameters for the adsorption of dye onto AC.

conclusion was consistent with the results obtained earlier where the adsorption of BG onto AC increased with increasing temperature. The negative values of $\Delta G$ demonstrate the spontaneous nature of the adsorption process under study at the limits of the temperatures used. The value of $\Delta G$ became more negative with increasing temperature; this showed that the adsorption process was favorable with increasing the temperature. The positive value of $\Delta S$ showed the increasing randomness at the solid/liquid interface during the adsorption of the BG dye onto AC. 
TABLE 3: Thermodynamic parameters for the adsorption of the BG dye onto AC.

\begin{tabular}{lcc}
\hline$T(\mathrm{~K})$ & $\Delta G\left(\mathrm{kJmol}^{-1}\right)$ & $\Delta H\left(\mathrm{kJmol}^{-1}\right)$ \\
\hline 298 & -81.188 & 43.025 \\
308 & -82.468 & \\
318 & -83.108 & \\
328 & -84.388 & \\
338 & -85.668 & \\
348 & -86.948 & \\
358 & -88.228 & \\
368 & -89.508 & \\
\hline
\end{tabular}

TABLE 4: Comparison between the present study and previous studies for the biosorption of the brilliant green dye from point of view of the operating parameters.

\begin{tabular}{|c|c|c|c|c|}
\hline Type & Material & $\begin{array}{l}\text { Variables } \mathrm{pH} \text {, temperature, } \\
\text { COD conc., water type }\end{array}$ & Removal (\%) & Ref. \\
\hline $\begin{array}{l}\text { EDTA-modified magnetic } \\
\text { sawdust carbon } \\
\text { nanocomposites (EDTA@ } \\
\mathrm{Fe}_{3} \mathrm{O}_{4} / \mathrm{SC} \text { ncs) }\end{array}$ & & $\begin{array}{c}\mathrm{pH}=7, \text { room temperature } \\
\left(27^{\circ} \mathrm{C}\right), \text { dye conc. } 10 \mathrm{mg} / \mathrm{l}, 0.5 \mathrm{~g} / \\
1,0.5 \mathrm{~h}\end{array}$ & 96.7 & [38] \\
\hline
\end{tabular}

\begin{tabular}{|c|c|c|c|c|}
\hline & $\begin{array}{c}\text { Cotton shell powder } \\
\text { (CSP) } \\
\text { Moringa oleifera } \\
\text { leaves (ML) } \\
\text { Magnetite-assisted } \\
\text { composites of } \\
\text { Moringa oleifera } \\
\text { leaves (MLMC) } \\
\text { Cotton shell powder } \\
\text { (CSPMC) }\end{array}$ & $\begin{array}{l}\text { At optimum dosage }(2 \mathrm{~g} / \mathrm{L}) \text {, } \\
\text { room temperature, dye conc. } \\
\quad 80 \mathrm{mg} / \mathrm{l} \text {, and } \mathrm{pH}=8\end{array}$ & 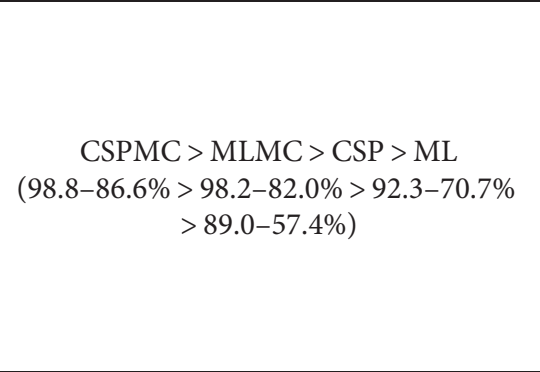 & [39] \\
\hline $\begin{array}{l}\text { Hydroxyapatite/chitosan } \\
\text { nanocomposite }\end{array}$ & & $\begin{array}{c}\mathrm{pH}=7, \text { room temperature } \\
\left(25^{\circ} \mathrm{C}\right), \text { dye conc. } 5 \mathrm{mg} / \mathrm{l}, 0.9 \mathrm{~g} / \mathrm{l} \\
1 \mathrm{~h}\end{array}$ & 99.5 & [40] \\
\hline $\begin{array}{l}\mathrm{Cu} 0.5 \mathrm{Mn} 0.5 \mathrm{Fe}_{2} \mathrm{O}_{4} \\
\text { nanospinel }\end{array}$ & & $\begin{array}{c}\mathrm{pH}=2-12, \text { room temperature } \\
\left(25^{\circ} \mathrm{C}\right), \text { dye conc. } 100 \mathrm{mg} / \mathrm{l} \\
3.3 \mathrm{~g} / \mathrm{l}, 2 \mathrm{~h}\end{array}$ & 92 & [41] \\
\hline $\begin{array}{l}\mathrm{MnO}_{2} \text {-loaded activated } \\
\text { carbon }\end{array}$ & & $\begin{array}{c}\mathrm{pH}=7, \text { room temperature } \\
\left(25^{\circ} \mathrm{C}\right) \text {, dye conc. } 6 \mathrm{mg} / \mathrm{l}, 0.44 \mathrm{~g} / \\
1,0.06 \mathrm{~h}\end{array}$ & 99 & {$[42]$} \\
\hline Kaolin & & $\begin{array}{c}90 \mathrm{~min}, \text { dye concentrations of } \\
20 \mathrm{mg} / \mathrm{L}, \mathrm{pH}=7 \text {, adsorbent } \\
\text { dose }=1 \mathrm{~g} / \mathrm{l}\end{array}$ & 91 & [2] \\
\hline $\begin{array}{l}\text { Activated carbon materials } \\
\text { were prepared from the } \\
\text { Brazilian pine-fruit shell } \\
\text { (Araucaria angustifolia) }\end{array}$ & $\begin{array}{l}\text { Chemically activated } \\
\text { carbon (CAC) } \\
\text { Chemically and } \\
\text { physically activated } \\
\text { carbon (CPAC) }\end{array}$ & $\begin{array}{c}5 \mathrm{~h} \text { at } 323 \mathrm{~K}, \mathrm{pH} 5.5 \text {; adsorbent } \\
\text { mass } 50.0 \mathrm{mg}\end{array}$ & $\begin{array}{l}\text { The maximum adsorption capacities } \\
\text { were } 273.9 \text { and } 335.8 \mathrm{mg} / \mathrm{g} \text { for } \mathrm{CAC} \text { and } \\
\text { CPAC, respectively }\end{array}$ & [43] \\
\hline $\mathrm{NaOH}$-treated saw dust & & $\begin{array}{l}\mathrm{pH}=2.9, \text { contact time }=3 \mathrm{~h} \text { and } \\
\text { adsorbent dose }=4 \mathrm{~g} / \mathrm{l} . T=3 \mathrm{~h}, \\
\text { temperature } 303 \mathrm{~K}\end{array}$ & 96 & {$[44]$} \\
\hline Red clay & & $\begin{array}{c}\mathrm{pH}=7, \mathrm{RC} \text { particle } \\
\text { size }=58 \mu \mathrm{m}, \text { contact time }=4 \mathrm{~h} \\
\text { and adsorbent dose }=0.4 \mathrm{~g} / \mathrm{L} \\
\text { and temperature } 25^{\circ} \mathrm{C} \text {, dye } \\
\text { conc. } 20 \mathrm{ppm}\end{array}$ & 96 & [7] \\
\hline ZnS-NP-AC 142.9 & & $\begin{array}{c}\mathrm{pH}=6 \text {, adsorbent } \\
\text { dose }=0.015 \mathrm{~g}, \text { time }=35 \mathrm{~min}, \\
\text { temperature: } 27 \pm 2^{\circ} \mathrm{C}, \mathrm{BG} \\
\text { conc. } 5 \mathrm{mg} / \mathrm{L}\end{array}$ & 98 & [45] \\
\hline
\end{tabular}


TABLE 4: Continued.

\begin{tabular}{|c|c|c|c|c|}
\hline Type & Material & $\begin{array}{l}\text { Variables } \mathrm{pH} \text {, temperature, } \\
\text { COD conc., water type }\end{array}$ & Removal (\%) & Ref. \\
\hline ZnS-NP-AC-BG 250 & $\begin{array}{c}\text { Zinc sulfide } \\
\text { nanoparticles loaded } \\
\text { on activated carbon } \\
(\mathrm{ZnS}-\mathrm{NPs}-\mathrm{AC})\end{array}$ & $\begin{array}{c}\mathrm{pH}=5,20 \mathrm{mg} \text { of } \mathrm{ZnS}-\mathrm{NP}-\mathrm{AC} \\
7 \mathrm{mg} \mathrm{L}^{-1} \text { of } \mathrm{BG} \text { after } 4 \mathrm{~min} \\
\text { sonication }\end{array}$ & $95 \%$ adsorption capacity $258 \mathrm{mg} \mathrm{g}^{-1}$ & {$[46]$} \\
\hline $\mathrm{ZnO}$ nanoparticles & & $\begin{array}{c}\text { Dye conc. } 10-100 \mathrm{mg} / \mathrm{L}, \text { temp. } \\
-27 \pm 1^{\circ} \mathrm{C} \text {, adsorbent dose } \\
0.04 \mathrm{~g} \text { and time } 120 \mathrm{~min} ., \mathrm{pH} \\
6.5 \pm 0.5\end{array}$ & 90 & {$[47]$} \\
\hline $\begin{array}{l}\text { Activated carbon derived } \\
\text { from guava tree wood }\end{array}$ & & $\begin{array}{l}\text { Time }\left(q_{\mathrm{t}}\right) \text { is } 20 \text { minutes, } \mathrm{pH} 7 \text {, } \\
\text { initial BG dye of } 25 \mathrm{mg} / \mathrm{l} \text { and } \\
\text { AC dosage greater than } 0.8 \mathrm{~g}\end{array}$ & 99 & $\begin{array}{l}\text { This } \\
\text { study }\end{array}$ \\
\hline
\end{tabular}

3.6. Comparison with Different Experimental Studies. The results concluded that green dye (BG) removal by adsorption was controlled by the nature of the adsorbent material which can be detected by the change in surface characteristics of the adsorbents with SEM and FTIR, $\mathrm{pH}$, adsorbent dosage, contact time, and the initial concentration of BG in contaminated water. Maximum removal of BG was obtained with activated carbon derived from guava tree wood (99\%) in the first $20 \mathrm{~min}$ at a dosage of $0.8 \mathrm{~g}$ with an adsorption potential of $90 \mathrm{mg} / \mathrm{g}$. In the future, column scale and pilot plant experiments can be implemented to be applied in the wastewater treatment plant for cationic and anionic textile dye removal from wastewater. Authors reported studies on the adsorption of brilliant green dye (BG) from water as illustrated in Table 4 with the different optimum conditions.

\section{Conclusion}

The removal of the brilliant green dye from wastewater using activated carbon derived from guava tree wood has been investigated under different experimental conditions in the batch mode. The FTIR results reveal that a large amount of chemical functional groups were well maintained and created on the surface of AC, which might improve its adsorptive properties due to the functional groups $\mathrm{O}-\mathrm{H},-\mathrm{CH}$ aliphatic, $-\mathrm{C}=\mathrm{C},-\mathrm{CH}_{2}$ bending, and $-\mathrm{C}=\mathrm{S}$. It also showed that the SEM analysis exhibited approval of the adsorption process due to the surface texture of the examined plant. The adsorbent $(\mathrm{AC})$ can completely remove the BG dye from an aqueous solution at the following conditions: $\mathrm{pH} 7$, initial BG dye of $25 \mathrm{mg} / \mathrm{l}$, and contact time 20 minutes. The adsorption efficiency increases with increasing dose, and the optimum dose is $0.8 \mathrm{~g}$ with the removal efficiency of $99 \%$ and adsorption capacity $\left(q_{e}\right)$ of $90 \mathrm{mg} \mathrm{BG}$ dye/g AC. The sorption of dye follows the Freundlich isotherm, indicating the heterogeneous adsorption surface with multilayer adsorption taking place on the heterogeneous $\mathrm{AC}$ from the guava tree surface's innumerous adsorption sites. This was also supported by the results of the kinetic study for BG dye removal, which were obtained following the pseudo-secondorder model. This model, used to clarify the probability of overall adsorption properties, was suited to the chemical adsorption mechanism. From the values of thermodynamic parameters, the adsorption process is spontaneous and endothermic. AC from the guava tree can be effectively used as an adsorbent comparable with the other commercial adsorbents used. AC from the guava tree wood is economically cheap, and so regeneration is not necessary.

\section{Data Availability}

All the necessary information required for replication of this work and/or conducting secondary analysis are included within the article.

\section{Conflicts of Interest}

The authors declare that they have no conflicts of interest.

\section{References}

[1] N. A. Youssef, S. A. Shaban, F. A. Ibrahim, and A. S. Mahmoud, "Degradation of methyl orange using Fenton catalytic reaction," Egyptian Journal of Petroleum, vol. 25, no. 3, pp. 317-321, 2016.

[2] B. K. Nandi, A. Goswami, and M. K. Purkait, "Adsorption characteristics of brilliant green dye on kaolin," Journal of Hazardous Materials, vol. 161, pp. 387-395, 2009.

[3] S. S. Behera, S. Das, P. K. Parhi, S. K. Tripathy, R. K. Mohapatra, and M. Debata, "Kinetics, thermodynamics and isotherm studies on adsorption of methyl orange from aqueous solution using ion exchange resin Amberlite IRA400," Desalination and Water Treatment, vol. 60, pp. 249-260, 2017.

[4] R. Kumar, M. O. Ansari, and M. A. Barakat, "Adsorption of brilliant green by surfactant doped polyaniline/MWCNTs composite: evaluation of the kinetic, thermodynamic, and isotherm," Industrial \& Engineering Chemistry Research, vol. 53, no. 17, pp. 7167-7175, 2014.

[5] M. Ghaedi, N. Zeinali, A. M. Ghaedi, M. Teimuori, and J. Tashkhourian, "Artificial neural network-genetic algorithm based optimization for the adsorption of methylene blue and brilliant green from aqueous solution by graphite oxide nanoparticle," Spectrochimica Acta Part A: Molecular and Biomolecular Spectroscopy, vol. 125, pp. 264-277, 2014.

[6] L. Zhang, X. Liu, X. Guo, M. Su, T. Xu, and X. Song, "Investigation on the degradation of brilliant green induced oxidation by $\mathrm{NiFe} 2 \mathrm{O} 4$ under microwave irradiation," Chemical Engineering Journal, vol. 173, no. 3, pp. 737-742, 2011. 
[7] M. S. U. Rehman, M. Munir, M. Ashfaq et al., "Adsorption of Brilliant Green dye from aqueous solution onto red clay," Chemical Engineering Journal, vol. 228, pp. 54-62, 2013.

[8] C. G. Kumar, P. Mongolla, J. Joseph, and V. U. M. Sarma, "Decolorization and biodegradation of triphenylmethane dye, brilliant green, by Aspergillus sp. isolated from Ladakh, India," Process Biochemistry, vol. 47, no. 9, pp. 1388-1394, 2012.

[9] Z. Ajji and A. M. Ali, "Adsorption of methyl violet and brilliant blue onto poly(vinyl alcohol) membranes grafted with N-vinyl imidazole/acrylic acid," Nuclear Instruments and Methods in Physics Research Section B: Beam Interactions with Materials and Atoms, vol. 265, no. 1, pp. 362-365, 2007.

[10] K. Kadirvelu, M. Kavipriya, C. Karthika, M. Radhika, N. Vennilamani, and S. Pattabhi, "Utilization of various agricultural wastes for activated carbon preparation and application for the removal of dyes and metal ions from aqueous solutions," Bioresource Technology, vol. 87, no. 1, pp. 129-132, 2003.

[11] S. Azizian, M. Haerifar, and H. Bashiri, “Adsorption of methyl violet onto granular activated carbon: equilibrium, kinetics and modeling," Chemical Engineering Journal, vol. 146, no. 1, pp. 36-41, 2009.

[12] H. Cherifi, S. Hanini, and F. Bentahar, "Adsorption of phenol from wastewater using vegetal cords as a new adsorbent," Desalination, vol. 244, no. 13, pp. 177-187, 2009.

[13] I. A. W. Tan, A. L. Ahmad, and B. H. Hameed, "Preparation of activated carbon from coconut husk: optimization study on removal of 2,4,6-trichlorophenol using response surface methodology," Journal of Hazardous Materials, vol. 153, no. 12, pp. 709-717, 2008.

[14] M. A. Islam, M. J. Ahmed, W. A. Khanday, M. Asif, and B. H. Hameed, "Mesoporous activated carbon prepared from $\mathrm{NaOH}$ activation of rattan (Lacosperma secundiflorum) hydrochar for methylene blue removal," Ecotoxicology and Environmental Safety, vol. 138, pp. 279-285, 2017.

[15] B. Murmu, S. Behera, S. Das, R. Mohapatra, B. Bindhani, and P. Parhi, Extensive Investigation on the Study for the Adsorption of Bromocresol Green (BCG) Dye Using Activated Phragmites Karka, NISCAIR-CSIR, New Delhi, India, 2018.

[16] S. Sinha, S. S. Behera, S. Das et al., "Removal of Congo Red dye from aqueous solution using Amberlite IRA-400 in batch and fixed bed reactors," Chemical Engineering Communications, vol. 205, no. 4, pp. 432-444, 2018.

[17] O. Ioannidou and A. Zabaniotou, "Agricultural residues as precursors for activated carbon production-A review," Renewable and Sustainable Energy Reviews, vol. 11, no. 9, pp. 1966-2005, 2007.

[18] P. Húmpola, H. Odetti, J. C. Moreno-Piraján, and L. Giraldo, "Activated carbons obtained from agro-industrial waste: textural analysis and adsorption environmental pollutants," Adsorption, vol. 22, no. 1, pp. 23-31, 2016.

[19] R. Shokoohi, V. Vatanpoor, M. Zarrabi, and A. Vatani, "Adsorption of acid red 18 (AR18) by activated carbon from poplar wood-A kinetic and equilibrium study," E-Journal of Chemistry, vol. 7, no. 1, pp. 65-72, 2010.

[20] A. E. Nemr, "Potential of pomegranate husk carbon for $\mathrm{Cr}(\mathrm{VI})$ removal from wastewater: kinetic and isotherm studies," Journal of Hazardous Materials, vol. 161, no. 1, pp. 132-141, 2009.

[21] A. A. Bakr, N. A. Sayed, T. M. Salama, I. O. Ali, R. R. Abdel Gayed, and N. A. Negm, "Kinetics and thermodynamics of $\mathrm{Mn}$ (II) removal from aqueous solutions onto $\mathrm{Mg}-\mathrm{Zn}-\mathrm{Al}$ LDH/montmorillonite nanocomposite," Egyptian Journal of Petroleum, vol. 27, no. 4, pp. 1215-1220, 2018.
[22] R. Mansour, A. El-Menshawy, and A. Eldesoky, "Separation of uranyl ion from different media using a new cellulose hydrazone: adsorption isotherms, kinetic and thermodynamic studies," International Journal of Advanced Research, vol. 3, pp. 966-980, 2015.

[23] I. A. W. Tan, A. L. Ahmad, and B. H. Hameed, "Adsorption isotherms, kinetics, thermodynamics and desorption studies of 2,4,6-trichlorophenol on oil palm empty fruit bunch-based activated carbon," Journal of Hazardous Materials, vol. 164, no. 2-3, pp. 473-482, 2009.

[24] J. Goscianska, M. Marciniak, and R. Pietrzak, "Mesoporous carbons modified with lanthanum(III) chloride for methyl orange adsorption," Chemical Engineering Journal, vol. 247, pp. 258-264, 2014.

[25] H. Mittal, A. Maity, and S. S. Ray, "Synthesis of co-polymergrafted gum karaya and silica hybrid organic-inorganic hydrogel nanocomposite for the highly effective removal of methylene blue," Chemical Engineering Journal, vol. 279, pp. 166-179, 2015.

[26] H. Mittal, V. Parashar, S. B. Mishra, and A. K. Mishra, "Fe3O4 MNPs and gum xanthan based hydrogels nanocomposites for the efficient capture of malachite green from aqueous solution," Chemical Engineering Journal, vol. 255, pp. 471-482, 2014.

[27] M. Fathy, M. El-Sayed, M. Ramzi, and O. H. Abdelraheem, "Adsorption separation of condensate oil from produced water using ACTF prepared of oil palm leaves by batch and fixed bed techniques," Egyptian Journal of Petroleum, vol. 27, no. 3, pp. 319-326, 2018.

[28] W. Janusz and E. Skwarek, "Study of sorption processes of strontium on the synthetic hydroxyapatite," Adsorption, vol. 22, no. 4-6, pp. 697-706, 2016.

[29] V. Garg, M. Amita, R. Kumar, and R. Gupta, "Basic dye (methylene blue) removal from simulated wastewater by adsorption using Indian Rosewood sawdust: a timber industry waste," Dyes and Pigments, vol. 63, no. 3, pp. 243-250, 2004.

[30] M. Auta and B. H. Hameed, "Optimized waste tea activated carbon for adsorption of Methylene Blue and Acid Blue 29 dyes using response surface methodology," Chemical Engineering Journal, vol. 175, pp. 233-243, 2011.

[31] N. Kannan and M. M. Sundaram, "Kinetics and mechanism of removal of methylene blue by adsorption on various carbonsa comparative study," Dyes and Pigments, vol. 51, no. 1, pp. 25-40, 2001.

[32] J. Eastoe and J. S. Dalton, "Dynamic surface tension and adsorption mechanisms of surfactants at the air-water interface," Advances in Colloid and Interface Science, vol. 85, no. 2-3, pp. 103-144, 2000.

[33] P. S. Kumar, S. Ramalingam, C. Senthamarai, M. Niranjanaa, P. Vijayalakshmi, and S. Sivanesan, "Adsorption of dye from aqueous solution by cashew nut shell: studies on equilibrium isotherm, kinetics and thermodynamics of interactions," Desalination, vol. 261, pp. 52-60, 2010.

[34] C. Pang, Y.-H. Liu, X.-H. Cao et al., "Biosorption of uranium(VI) from aqueous solution by dead fungal biomass of Penicillium citrinum," Chemical Engineering Journal, vol. 170, no. 1, pp. 1-6, 2011.

[35] F. E. Huggins, G. P. Huffman, A. Kolker, S. J. Mroczkowski, C. A. Palmer, and R. B. Finkelman, "Combined application of XAFS spectroscopy and sequential leaching for determination of arsenic speciation in coal," Energy \& Fuels, vol. 16, no. 5, pp. 1167-1172, 2002.

[36] M. A. M. Salleh, D. K. Mahmoud, W. A. W. A. Karim, and A. Idris, "Cationic and anionic dye adsorption by agricultural 
solid wastes: a comprehensive review," Desalination, vol. 280, no. 1-3, pp. 1-13, 2011.

[37] A. Yargıç, R. Y. Şahin, N. Özbay, and E. Önal, “Assessment of toxic copper (II) biosorption from aqueous solution by chemically-treated tomato waste," Journal of Cleaner Production, vol. 88, pp. 152-159, 2015.

[38] N. Kataria and V. K. Garg, "Application of EDTA modified $\mathrm{Fe} 3 \mathrm{O} 4 /$ sawdust carbon nanocomposites to ameliorate methylene blue and brilliant green dye," Environmental Research, vol. 172, pp. 43-54, 2019.

[39] M. Imran, A. U. Islam, M. A. Tariq et al., "Synthesis of magnetite-based nanocomposites for effective removal of brilliant green dye from wastewater," Environmental Science and Pollution Research, vol. 26, pp. 24489-24502, 2019.

[40] A. Ragab, I. Ahmed, and D. Bader, "The removal of brilliant green dye from aqueous solution using nano hydroxyapatite/ chitosan composite as a sorbent," Molecules, vol. 24, p. 847, 2019.

[41] S. Hashemian, A. Dehghanpor, and M. Moghahed, "Cu0.5Mn0.5Fe2O4 nano spinels as potential sorbent for adsorption of brilliant green," Journal Industrial \& Engineering Chemistry, vol. 24, pp. 308-314, 2015.

[42] A. Asfaram, M. Ghaedi, S. Hajati, and A. Goudarzi, "Ternary dye adsorption onto $\mathrm{MnO} 2$ nanoparticle-loaded activated carbon," RSC Advances, vol. 5, pp. 72300-72320, 2015.

[43] T. Calvete, E. C. Lima, N. F. Cardoso, S. L. P. Dias, and E. S. Ribeiro, "Removal of brilliant green dye from aqueous solutions using home made activated carbons," CLEAN-Soil, Air, Water, vol. 38, pp. 521-532, 2010.

[44] V. S. Mane and P. V. Babu, "Studies on the adsorption of Brilliant Green dye from aqueous solution onto low-cost $\mathrm{NaOH}$ treated saw dust," Desalination, vol. 273, pp. 321-329, 2011.

[45] M. Ghaedi, A. Ansari, F. Bahari, A. Ghaedi, and A. Vafaei, "A hybrid artificial neural network and particle swarm optimization for prediction of removal of hazardous dye brilliant green from aqueous solution using zinc sulfide nanoparticle loaded on activated carbon," Spectrochimica Acta Part A: Molecular and Biomolecular Spectroscopy, vol. 137, pp. 1004-1015, 2015.

[46] M. Jamshidi, M. Ghaedi, K. Dashtian et al., "Highly efficient simultaneous ultrasonic assisted adsorption of brilliant green and eosin $\mathrm{B}$ onto $\mathrm{ZnS}$ nanoparticles loaded activated carbon: artificial neural network modeling and central composite design," Spectrochimica Acta Part A: Molecular and Biomolecular Spectroscopy, vol. 153, pp. 257-267, 2016.

[47] N. Kataria and V. K. Garg, "Removal of Congo red and Brilliant green dyes from aqueous solution using flower shaped $\mathrm{ZnO}$ nanoparticles," Journal of Environmental Chemical Engineering, vol. 5, no. 1-3, pp. 5420-5428, 2017. 